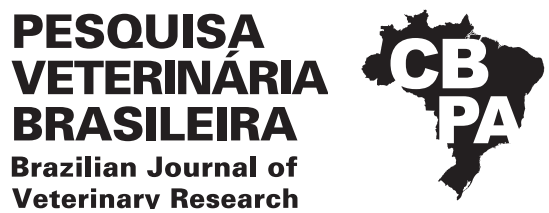

Pesq. Vet. Bras. 41:e06886, 2021 DOI: 10.1590/1678-5150-PVB-6886

Original Article Livestock Diseases

ISSN 0100-736X (Print)

ISSN 1678-5150 (Online)

\title{
Causes of death in sheep in Rio Grande do Sul, Brazil: analysis of 523 cases $(2004-2019)^{1}$
}

\author{
Bianca S. Cecco ${ }^{2 *}(\mathbb{D})$, Franciéli A. Molossi² ${ }^{(\mathbb{D}}$, Luan C. Henker² (D), \\ Marina P. Lorenzett ${ }^{2}$ D , Gabriel L.F. Correa ${ }^{2}$, David Driemeier ${ }^{2}$ (D), \\ Saulo P. Pavarini ${ }^{2}$ (D) and Luciana Sonne ${ }^{2}$ (D)
}

\begin{abstract}
Cecco B.S., Molossi F.A., Henker L.C., Lorenzett M.P., Correa G.L.F., Driemeier D., Pavarini S.P. \& Sonne L. 2021. Causes of death in sheep in Southern Brazil: analysis of 523 cases (2004-2019). Pesquisa Veterinária Brasileira 41:e06886, 2021. Setor de Patologia Veterinária, Departamento de Patologia Clínica Veterinária, Faculdade de Veterinária, Universidade Federal do Rio Grande do Sul, Av. Bento Gonçalves 9090, Prédio 42505, Porto Alegre, RS 91540-000, Brazil. E-mail: biasantanacecco@gmail.com

The increase in the commercialization of sheep products requires an equivalent improvement in flock health and rapid disease identification. Data regarding the cause of death in sheep were reviewed from the database of the "Setor de Patologia Veterinária" from the "Universidade Federal do Rio Grande do Sul", from January 2004 and December 2019. Epidemiological features, such as breed, sex, and age, in addition to the clinical and pathological features, were analyzed. During this period, tissues from 523 sheep were evaluated, in which a conclusive diagnosis was obtained in 457 (87\%) of the cases. The majority of sheep were from the metropolitan mesoregion of Porto Alegre. The most common breed was Texel 171/523 (33\%). From all the conclusive diagnoses, 158/457 (35\%) corresponded to infectious non-parasitic diseases, 117/457 (26\%) were caused by toxic etiology, 95/457 (21\%) were infectious parasitic diseases, $42 / 457(9 \%)$ were included in the nutritional and metabolic category, 38/457 (8\%) were in the "others" category, and 7/457 (1.5\%) were congenital defects. The age of sheep included in this study ranged from 1 day to 7 years. Among cases with conclusive diagnosis, the main cause of death was haemonchosis with 83/457 (18\%) of cases, followed by pneumonia 29/457 (6\%), Baccharis sp. poisoning 25/457 (5\%), and bluetongue 22/457 (5\%).
\end{abstract}

INDEX TERMS: Diagnosis, ovine, pathology, small ruminants, infectious disease, sheep, Brazil.

RESUMO.- [Causas de morte em ovinos no Sul do Brasil: análise de 523 casos (2004-2019).] $O$ aumento da comercialização de produtos ovinos requer um aumento equivalente na sanidade do rebanho e uma rápida identificação de doenças. Os dados sobre as causas de morte em ovinos foram revisados no banco de dados do Setor de Patologia Veterinária da Universidade Federal do Rio Grande do Sul, entre janeiro de 2004 e dezembro de 2019. Aspectos epidemiológicos, como raça, sexo e idade, além das características clínicas e patológicas, foram compilados. Nesse período, foram avaliados tecidos de 523 ovinos, em que o diagnóstico conclusivo foi

\footnotetext{
${ }^{1}$ Received on April 19, 2021.

Accepted for publication on May 4, 2021.

${ }^{2}$ Setor de Patologia Veterinária, Departamento de Patologia Clínica Veterinária, Faculdade de Veterinária, Universidade Federal do Rio Grande do Sul (UFRGS), Av. Bento Gonçalves 9090, Prédio 42505, Porto Alegre, RS 91540-000, Brazil. *Corresponding author: biasantanacecco@gmail.com
}

obtido em 457 (87\%) dos casos. A grande maioria dos ovinos era da mesorregião metropolitana de Porto Alegre. A raça mais comum foi Texel 171/523 (33\%). De todos os diagnósticos conclusivos, 158/457 (35\%) corresponderam a doenças infecciosas não-parasitárias, 117/457 (26\%) foram causadas por doenças tóxicas, 95/457 (21\%) doenças infecciosas parasitárias, $42 / 457$ (9\%) foram incluídos na categoria nutricional e metabólica, 38/457 (8\%) foram classificadas na categoria "outros", e $7 / 457$ (1,5\%) eram defeitos congênitos. A faixa etária das ovelhas incluídas neste estudo foi de um dia a sete anos de idade. Entre os casos com diagnóstico conclusivo, a principal causa de óbito foi hemoncose com 83/457 (18\%) dos casos, seguida de pneumonia 29/457 (6\%), intoxicação por Baccharis sp. 25/457 (5\%), e infecção pelo vírus da língua azul 22/457 (5\%).

TERMOS DE INDEXAÇÃO: Diagnóstico, ovinos, patologia, pequenos ruminantes, doenças infecciosas, Brasil. 


\section{INTRODUCTION}

In the middle ' 80 s and during the ' 90 s, because of a significant decrease in wool value, due to synthetic fabric production and commercialization, there was a drastic reduction of sheep flocks in the State of Rio Grande do Sul (Viana \& Silveira 2009). However, the recent lamb meat valorization, caused a new wave of investment in this species, leading to an increase in Rio Grande do Sul flock, reaching up to 3 million sheep (IBGE 2018). The production growth requires appropriate flock health and the development of disease prevention programs since the significant increase in sheep flock is accompanied by the increase of reported diseases and mortality (Rissi et al. 2010b).

Mortality in this species is frequently related to a main group of agents: infectious and parasitic (Rissi et al. 2010a, 2010b, Almeida et al. 2013, Correa 2014). Infectious diseases are responsible for severe economic losses and low productivity (Viana \& Silveira 2009, Rissi et al. 2010b, Almeida et al. 2013). Besides infectious and parasitic agents, diseases of toxic origin, such as plant or copper poisoning, and metabolic and nutritional causes are also described (Rissi et al. 2010b, Correa 2014). This study aims to determine the main causes of death in sheep in the State of Rio Grande do Sul, from January 2004 to December 2019, with an emphasis on the metropolitan mesoregion of Porto Alegre, through the epidemiological, clinicopathological, and etiological characterization of post mortem examinations.

\section{MATERIALS AND METHODS}

We conducted a retrospective study of causes of death in sheep at the necropsy and biopsy database of the "Setor de Patologia Veterinária" of the "Universidade Federal do Rio Grande do Sul" (SPV-UFRGS), from January 2004 to December 2019. We reviewed the protocols of all sheep, and registered information regarding the cause of death, breed, age, and sex. Gross lesions were evaluated through photographs and combined with the previous descriptions available on the necropsy and biopsy reports. The cases were grouped into categories: infectious non-parasitic, infectious parasitic, toxic, nutritional and metabolic, congenital defects, and cases that did not fit in the above-mentioned etiologies were categorized as "others". The inconclusive diagnosis was considered when the protocols did not establish a definitive cause of death. Only sheep referred from cities located in the State of Rio Grande do Sul were included in the study. Aborted and stillborn fetuses, slaughter, as well as sheep that were used in experimental studies were not included.

Post mortem procedures included gross and microscopic examination of the main organs. The tissues were fixed in 10\% buffered formalin, routinely processed, paraffin-embedded, sectioned at $5 \mu \mathrm{m}$, and stained with hematoxylin and eosin (HE) for evaluation in an optical microscope. When necessary, complementary tests were performed, such as immunofluorescence to confirm the diagnosis of rabies, as well as virology, bacteriological, parasitology, and immunohistochemical tests.

\section{RESULTS}

From January 2004 to December 2019, we analyzed tissues from 523 sheep, in which $361 / 523$ post mortem examinations were performed by veterinary pathologists from SPV-UFRGS, and the remaining 162 post mortem examinations were performed by field veterinarians, in which the organ fragments collected were sent to SPV-UFRGS for histopathological analysis. Of the 523 cases, 457 cases had a definitive diagnosis (87\%), while 66 cases $(13 \%)$ were classified as inconclusive. Of the 66 inconclusive diagnoses, in 35 (53\%) cases, post mortem examinations were performed by field veterinarians; while 31 (47\%) were performed by veterinary pathologists. Most inconclusive diagnoses were associated with severe autolysis or incomplete submission of organs to analysis.

All sheep were from properties located in the State of Rio Grande do Sul, mainly in the metropolitan mesoregion of Porto Alegre (60.4\%), followed by the northeast mesoregion $(7.5 \%)$, central-eastern mesoregion (4.8\%), southeast mesoregion (4.6\%), northwest mesoregion (1.7\%), south-west mesoregion (1.1\%). In 104 of cases (19.9\%), data regarding location was not available. The most common breeds observed were Texel $171 / 523$ (32\%), not informed 145/523 (28\%), mixed breed 99/523 (19\%), Suffolk 29/523 (6\%), Corriedale 25/523 (5\%), Hampshire Down 14/523 (3\%), Ile de France 13/523 (2\%), Dorper 9/523 (2\%), Lacaune 6/523 (1\%), Santa Inês 5/523 (0.9\%), Criollo 4/523 (0.7\%), and Merino 3/523 (0.5\%). Females accounted for 296/523 (57\%) sheep, and males accounted for $166 / 523$ (32\%) animals, while in the remaining 61 protocols sex was not informed.

From all the conclusive diagnosis, 158/457 (35\%) corresponded to infectious non-parasitic diseases; $117 / 457$ (26\%) were caused by toxic etiology; 95/457 (21\%) were infectious parasitic diseases; $42 / 457$ (9\%) were nutritional and metabolic; 38/457 (8\%) were included in the "others" category, and $7 / 457$ (1.5\%) were congenital defects. The frequency and epidemiological data regarding the main infectious disease in the studied period are presented in Table 1.

In the category of infectious non-parasitic diseases, pneumonia was frequently observed. Most cases of pneumonia were bacterial or aspiration, with a bacterial agent involved (29/37). A few bacterial agents were detected, such as Mannheimia haemolytica, Pasteurella sp., and Streptococcus sp. While other cases of pneumonia could not be associated with a specific cause, viral, or bacteria (8/37). Few cases of listeriosis had a history, and in only two cases poor quality silage could be associated with the condition. None of the sheep with listeriosis had gross lesions, including primary traumatic lesions in the mouth. In the cases of tetanus, the diagnosis was made through the association of a consistent history of caudectomy/castration, plus clinical signs of stiffness, and absence of gross and histological lesions.

The cases of poisoning included in the category of toxic diseases were related to the consumption of the substances described in Table 2. Few cases were epidemiologically, grossly and histologically compatible with a poisoning, however, no substance could be identified. In cases of toxic myopathy, and generalized calcification of toxic cause, although no substance could be identified we believe that plants such as Senna sp., and Nierembergia veitchii, may be involved. In cases of lysosomal accumulation disease, the disease was caused by Sida carpinifolia. degenerative lesions of CNS considered to be of toxic cause were grouped in the category of toxic disease through epidemiological and histological characteristics of the case.

Infectious parasitic diseases were responsible for $21 \%$ of the conclusive cases, and these cases are described in Table 3. Haemonchosis was observed in sheep with an age range from two months to seven years old. The diagnosis of the parasitic 
diseases was made through gross examination associated with histology, and parasitology test (fecal flotation), when the parasites, specifically Haemonchus contortus were not visualized during the post mortem examination. The diseases included in the nutritional and metabolic diseases category are described in Table 4. Ruminal acidosis was the most frequent disease, and all cases were associated with a history of abrupt change in the diet with a marked increase in grain consumption. Urolithiasis was identified more frequently in males. Hypoglycemia cases were described in lambs, with age ranging from one to three days old, and were related to the insufficient consumption of milk and colostrum.

Regarding the "other" category, cases of acute pulmonary edema were the main cause of death in our study, however, the etiology could not be defined. Traumas described in this study were associated with accidents involving other species, including dogs and horses (Table 5). In the congenital defect category (1.5\%/total), we observed: multiple congenital malformations described in Table 6. The etiologic agent was not identified in any of these cases. These congenital defects were diagnosed in lambs with ages ranging from one day to one month.

\section{DISCUSSION}

The expansion of sheep production is dependent on many factors, including appropriate nutrition, genetics, and sanity. To obtain high sanity standards, the diseases responsible for affecting sheep flocks in determined regions must be known by field veterinarians and owners, in order to be prevented, or rapidly recognized and resolved. Post mortem examination is an important diagnostic tool that leads to disease identification, and therefore, helps the maintenance of the flock's sanity. Conclusive diagnosis in the ovine species is highly dependent on the material condition, especially due to autolysis, which occurs faster in sheep than in other species, and is related to the wool, which prevents heat dissipation. The agility to

Table 1. Frequency and epidemiological data regarding the infectious non-parasitic diseases in sheep, from January 2004 to December 2019

\begin{tabular}{|c|c|c|c|c|}
\hline Disease & Cases & $\% /$ Category & \%/Total & Age $(\mathrm{d} / \mathrm{m})^{* *}$ \\
\hline Pneumonia & 38 & 24 & 8 & $1 d-48 m(18 m)$ \\
\hline Bluetongue & 22 & 14 & 5 & $3-18 \mathrm{~m}(8 \mathrm{~m})$ \\
\hline Listeriosis & 9 & 6 & 2 & $4-60 m(24 m)$ \\
\hline Tetanus & 9 & 6 & 2 & $15 \mathrm{~d}-4 \mathrm{~m}(2 \mathrm{~m})$ \\
\hline SRLV & 8 & 5 & 2 & $18-84 \mathrm{~m}(36 \mathrm{~m})$ \\
\hline CNS abscess & 7 & 4 & 2 & $1-36$ m (12m) \\
\hline Enterotoxemia & 6 & 4 & 1 & $1-5 \mathrm{~m}(1 \mathrm{~m})$ \\
\hline Scrapie & 5 & 3 & 1 & $30-36 \mathrm{~m}(33 \mathrm{~m})$ \\
\hline Salmonellosis & 5 & 3 & 1 & $3-48$ m (18m) \\
\hline Bacterial enteritis & 5 & 3 & 1 & $7 d-48 m(6 m)$ \\
\hline Septicemia & 5 & 3 & 1 & $12-42 \mathrm{~m}(18 \mathrm{~m})$ \\
\hline Rabies & 4 & 3 & 1 & 8-18 m (12m) \\
\hline Bacterial osteomyelitis & 3 & 2 & 0.5 & $24 \mathrm{~m}(24 \mathrm{~m})$ \\
\hline Bacterial endocarditis & 3 & 2 & 0.5 & $12-24 \mathrm{~m}(24 \mathrm{~m})$ \\
\hline Suppurative myelomalacia by Proteus mirabilis & 3 & 2 & 0.5 & $1 \mathrm{~m}(1 \mathrm{~m})$ \\
\hline Bacterial peritonitis & 3 & 2 & 0.5 & $1-48 \mathrm{~m}(3 \mathrm{~m})$ \\
\hline Bacterial epididymitis & 2 & 1.3 & 0.5 & $72 \mathrm{~m}(72 \mathrm{~m})$ \\
\hline Malignant edema & 2 & 1.3 & 0.5 & $6-36 \mathrm{~m}(21 \mathrm{~m})$ \\
\hline Caseous lymphadenitis & 2 & 1.3 & 0.5 & $24-60 \mathrm{~m}(8 \mathrm{~m})$ \\
\hline Mycotic rhinitis by Conidiobolus sp. & 2 & 1.3 & 0.5 & $24-36 \mathrm{~m}(30 \mathrm{~m})$ \\
\hline Purulent arthritis & 2 & 1.3 & 0.5 & $24 \mathrm{~m}(24 \mathrm{~m})$ \\
\hline Spondylitis with spinal cord compression & 2 & 1.3 & 0.5 & $24-120 \mathrm{~m}(72 \mathrm{~m})$ \\
\hline Yellow lamb disease & 1 & 0.6 & 0.2 & $1 \mathrm{~m}(1 \mathrm{~m})$ \\
\hline Nasal enzootic tumor (ENTV-1) & 1 & 0.6 & 0.2 & $36 \mathrm{~m}(36 \mathrm{~m})$ \\
\hline Pulmonary cryptococcosis & 1 & 0.6 & 0.2 & $24 \mathrm{~m}(24 \mathrm{~m})$ \\
\hline Phlegmon by Arcanobacterium sp. & 1 & 0.6 & 0.2 & $36 \mathrm{~m}(36 \mathrm{~m})$ \\
\hline Abomasitis by Sarcina spp. & 1 & 0.6 & 0.2 & $1 \mathrm{~m}(1 \mathrm{~m})$ \\
\hline Esophagitis of undetermined cause & 1 & 0.6 & 0.2 & $12 \mathrm{~m}(12 \mathrm{~m})$ \\
\hline Gastric candidiasis & 1 & 0.6 & 0.2 & $9 \mathrm{~m}(9 \mathrm{~m})$ \\
\hline Mononuclear enteritis & 1 & 0.6 & 0.2 & NI \\
\hline Mycotic meningoencephalitis & 1 & 0.6 & 0.2 & $36 \mathrm{~m}(36 \mathrm{~m})$ \\
\hline Bacterial hepatitis* & 1 & 0.6 & 0.2 & NI \\
\hline Bacterial meningitis by Trueperella pyogenes & 1 & 0.6 & 0.2 & $30 \mathrm{~m}(30 \mathrm{~m})$ \\
\hline TOTAL & 158 & 100 & 35 & 18 \\
\hline
\end{tabular}

$\mathrm{d}$ = Days, $\mathrm{m}$ = months, SRLV = small ruminant lentivirus, $\mathrm{NI}=$ not informed; ${ }^{*}$ Etiology not defined, ${ }^{* *}$ median age (mo). 
perform the post mortem examination and proper shipping of the material collected can help improve the frequency of conclusive diagnoses. This could explain the high percentage of conclusive diagnoses we found in this study: 87\% (457/523) of the cases, while in other studies in Brazil they found $67.4 \%$ of conclusive cases in the Midwest of Brazil (Almeida et al. 2013), and 74.8\% in the central region of Rio Grande do Sul (Rissi et al. 2010b).

Table 2. Frequency and epidemiological data regarding the toxic diseases diagnosed in sheep, from January 2004 to December 2019

\begin{tabular}{|c|c|c|c|c|}
\hline Disease & Cases & \%/Category & $\% /$ Total* & Age $(d / m)^{* *}$ \\
\hline Baccharis coridifolia poisoning & 25 & 21 & 5 & $15 \mathrm{~d}-144 \mathrm{~m}(48 \mathrm{~m})$ \\
\hline Copper poisoning & 20 & 17 & 4 & $24-48 \mathrm{~m}(24 \mathrm{~m})$ \\
\hline Ionophore poisoning & 14 & 12 & 3 & $3-24 \mathrm{~m}(9.5 \mathrm{~m})$ \\
\hline Acute toxic liver disease & 12 & 10 & 3 & $3-120 \mathrm{~m}(24 \mathrm{~m})$ \\
\hline Hepatic photosensitization & 8 & 7 & 2 & $2-42 \mathrm{~m}(36 \mathrm{~m})$ \\
\hline Brachiaria sp. photosensitization & 7 & 6 & 2 & $2-48 m(3 m)$ \\
\hline Trema micrantha poisoning & 2 & 1.7 & 0.5 & $12 \mathrm{~m}(12 \mathrm{~m})$ \\
\hline Amorimia exotropica poisoning & 2 & 1.7 & 0.5 & $30-72 \mathrm{~m}(51 \mathrm{~m})$ \\
\hline Strychnine poisoning & 2 & 1.7 & 0.5 & $24 \mathrm{~m}(24 \mathrm{~m})$ \\
\hline Ricinus communis poisoning & 2 & 1.7 & 0.5 & $12-24 \mathrm{~m}(18 \mathrm{~m})$ \\
\hline Hovenia dulcis poisoning & 2 & 1.7 & 0.5 & NI \\
\hline Generalized calcification of toxic cause*** & 1 & 1 & 0.2 & $36 \mathrm{~m}(36 \mathrm{~m})$ \\
\hline Degenerative lesions of CNS of toxic origin*** & 1 & 1 & 0.2 & $8 \mathrm{~m}(8 \mathrm{~m})$ \\
\hline Ateleia glazioviana poisoning & 1 & 1 & 0.2 & $36 \mathrm{~m}(36 \mathrm{~m})$ \\
\hline TOTAL & 117 & 100 & 26 & 24 \\
\hline
\end{tabular}

$\mathrm{d}$ = Days, $\mathrm{m}=$ months, $\mathrm{NI}=$ not informed; ${ }^{*}$ Refers to conclusive diagnoses, ${ }^{* *}$ median age (mo), ${ }^{* * *}$ etiology not defined.

Table 3. Frequency and epidemiological data regarding the infectious parasitic diseases diagnosed in sheep from January 2004 to December 2019

\begin{tabular}{lcccc}
\hline \multicolumn{1}{c}{ Disease } & Cases & \%/Category & \%/Total & Age $(\mathrm{d} / \mathrm{m})^{* *}$ \\
\hline Hemoncosis & 83 & 87 & 18 & $2-108 \mathrm{~m}(12 \mathrm{~m})$ \\
Fasciolosis & 6 & 6 & 1.3 & $12-48 \mathrm{~m}(24 \mathrm{~m})$ \\
Cerebral cenurosis & 3 & 3 & 0.6 & $12 \mathrm{~m}(24 \mathrm{~m})$ \\
Eimeriosis & 2 & 2 & 0.4 & $3 \mathrm{~m}(3 \mathrm{~m})$ \\
Granulomatous lymphadenitis of parasitic origin & 1 & 1 & 0.2 & $24 \mathrm{~m}(24 \mathrm{~m})$ \\
TOTAL & 95 & 100 & 21 & 24
\end{tabular}

$\overline{\mathrm{d}}=$ Days, $\mathrm{m}$ = months; ${ }^{*}$ Refers to conclusive diagnoses, ${ }^{* *}$ median age (mo).

Table 4. Frequency and epidemiological data regarding the nutritional and metabolic diseases diagnosed in sheep from January 2004 to December 2019

\begin{tabular}{|c|c|c|c|c|}
\hline Disease & Cases & \%/Category & $\% /$ Total* & $\operatorname{Age}(d / m)^{* *}$ \\
\hline Ruminal acidosis & 18 & 43 & 4 & $1-24 m(11 m)$ \\
\hline Urolithiasis & 8 & 19 & 2 & $4-12 m(7 m)$ \\
\hline Ketosis & 4 & 10 & 0.8 & $4-36 m(24 m)$ \\
\hline Hypoglycemia & 3 & 7 & 0.6 & $1-6 \mathrm{~d}(3 \mathrm{~d})$ \\
\hline Vit. E and Se deficiency & 3 & 7 & 0.6 & $20 \mathrm{~d}-2 \mathrm{~m}(1.5 \mathrm{~m})$ \\
\hline Polioencephalomalacia*** & 2 & 5 & 0.4 & $12-36 \mathrm{~m}(24 \mathrm{~m})$ \\
\hline Malnutrition anemia & 2 & 5 & 0.2 & $12 \mathrm{~m}(12 \mathrm{~m})$ \\
\hline Necrotic ruminitis $* * *$ & 1 & 2 & 0.2 & $72 \mathrm{~m}(72 \mathrm{~m})$ \\
\hline Fibrous osteodystrophy & 1 & 2 & 0.2 & $4 \mathrm{~m}(4 \mathrm{~m})$ \\
\hline TOTAL & 42 & 100 & 9 & 8 \\
\hline
\end{tabular}

d = Days, $\mathrm{m}=$ months, ${ }^{*}$ Refers to conclusive diagnoses, ${ }^{* *}$ median age (mo), ${ }^{* *}$ etiology not defined. 
In this study, most sheep were from the metropolitan mesoregion of Porto Alegre. The most common cause of death associated with this species was related to infectious nonparasitic diseases, followed by toxic and infectious parasitic diseases. These results are similar to what is described previously in South Brazil (Rissi et al. 2010b). Although the category of infectious parasitic disease represented the third most common cause of death in sheep, haemonchosis was still the most frequent cause of death, which is in accordance with the literature (Rissi et al. 2010b, Almeida et al. 2013). Nutritional and metabolic disease represented only $9 \%$ of conclusive diagnosis, and this feature is closely related to grazing system applied to sheep production in the state, that varies between extensive and semi-extensive system (Viana \& Silveira 2009), therefore, sheep have more access to toxic plants, and less to commercial feed or are fed with an excess of carbohydrates.

In the infectious non-parasitic category, the most common cause of death was pneumonia. The frequency of types of pneumonia in our study is similar to the frequency of general pneumonia in the Brazilian Midwest (10\%) (Almeida et al. 2013). Most cases of pneumonia in our study were related to bacterial agents such as Mannheimia haemolytica. Some predisposing factors to bacterial agents in sheep observed in cases of our study are similar to what is described in goats (Bassuino et al. 2018) and include stress, low temperatures, transportation, the mixture of animals of different origins, and subclinical haemonchosis. Pneumonia caused by $M$. haemolytica is characterized as cranioventral lobar or lobular fibrinous bronchopneumonia, foci of coagulative necrosis, and variable fibrinous pleuritis (Caswell \& Williams 2016). In addition, among bacterial pneumonia, we observed a frequent association with aspiration pneumonia. This type of pneumonia is caused by the aspiration of foreign material, which reaches the lungs through the airways, and the occurrence depends on three main factors: the nature of the material that was inhaled, the bacteria that was carried by the foreign material, and the distribution of the material in the lungs (Caswell \& Williams 2016). This condition can be related to many factors, such as force-feeding, diseases that course with vomiting and regurgitation, recumbency, and neurologic disease (Caswell \& Williams 2016). In our study, we were unable to identify a correlation between the high occurrence of aspiration pneumonia with a primary disease, however, we consider that subclinical haemonchosis or other parasites may be involved in this condition.

Bluetongue was the second most common infectious non-parasitic disease diagnosed in our study. Bluetongue (BT), is caused by an Orbivirus, named bluetongue virus (BTV). The disease can affect domestic and wild ruminants; however, clinical signs are seen almost exclusively in sheep and consist of respiratory distress, greenish seromucous or mucous nasal discharge, cyanotic oral mucosa, and ulcerative lesions in the oral cavity (Antoniassi et al. 2010a, Bianchi et al. 2017, Guimarães et al. 2017). The gross lesions that can lead to suspect this infection is characterized by epicardial and endocardial hemorrhages, hemorrhage in the mitral valve and in the base of the pulmonary artery, and heavy,

Table 5. Frequency and epidemiological data regarding the "others" diseases diagnosed in sheep from January 2004 to December 2019

\begin{tabular}{|c|c|c|c|c|}
\hline Disease & Cases & $\% /$ Category & \%/Total* & Age $(\mathrm{d} / \mathrm{m})^{* *}$ \\
\hline Polytrauma & 17 & 45 & 4 & $1-72 \mathrm{~m}(24 \mathrm{~m})$ \\
\hline Acute pulmonary edema & 9 & 24 & 2 & $24-48 \mathrm{~m}(24 \mathrm{~m})$ \\
\hline Ulcerative abomasitis & 3 & 8 & 0.6 & $1-24 \mathrm{~m}(24 \mathrm{~m})$ \\
\hline Intestinal torsion & 2 & 5 & 0.4 & $2 \mathrm{~d}(2 \mathrm{~d})$ \\
\hline Hepatic cirrhosis & 2 & 5 & 0.4 & NI \\
\hline Hepatocellular carcinoma & 1 & 2.6 & 0.2 & $18 \mathrm{~m}(18 \mathrm{~m})$ \\
\hline Uterine rupture with peritonitis & 1 & 2.6 & 0.2 & $24 \mathrm{~m}(24 \mathrm{~m})$ \\
\hline Membranoproliferative glomerulonephritis & 1 & 2.6 & 0.2 & $12 \mathrm{~m}(12 \mathrm{~m})$ \\
\hline TOTAL & 38 & 100 & 8 & 24 \\
\hline
\end{tabular}

$\mathrm{d}$ = Days, $\mathrm{m}=$ months, $\mathrm{NI}=$ not informed; ${ }^{*}$ Refers to conclusive diagnoses, ${ }^{* *}$ median age (mo), ${ }^{* * *}$ etiology not defined.

Table 6. Frequency and epidemiological data regarding the congenital defect diseases diagnosed in sheep from January 2004 to December 2019

\begin{tabular}{|c|c|c|c|c|}
\hline Disease & Cases & \%/Category & $\% /$ Total* & Age $(d / m)^{* *}$ \\
\hline Multiple congenital malformations & 1 & 14 & 0.2 & $1 \mathrm{~d}(1 \mathrm{~d})$ \\
\hline Cerebellar hypoplasia & 1 & 14 & 0.2 & $1 \mathrm{~m}(1 \mathrm{~m})$ \\
\hline Congenital microphthalmia & 1 & 14 & 0.2 & $20 \mathrm{~d}(20 \mathrm{~d})$ \\
\hline Tetralogy of Fallot & 1 & 14 & 0.2 & $3 \mathrm{~m}(3 \mathrm{~m})$ \\
\hline Agenesis of the cerebellar vermis & 1 & 14 & 0.2 & $1 \mathrm{~d}(1 \mathrm{~d})$ \\
\hline
\end{tabular}

$\mathrm{d}$ = Days, $\mathrm{m}=$ months; ${ }^{*}$ Refers to conclusive diagnoses, ${ }^{* *}$ median age (mo). 
reddened, and shiny lungs, with rib impressions (severe pulmonary edema) (Guimarães et al. 2017). In our study, BT occurred as outbreaks, leading to a higher number of cases when compared to other studies (Antoniassi et al. 2010a, 2010b, Guimarães et al. 2017).

Listeriosis is caused by a bacterium named Listeria monocytogenes and it has been described as an important cause of meningoencephalitis in small ruminants (Konradt et al. 2017). This condition is clinically characterized by head tilt, walk in circles, blindness and fever. Histologically, the main feature is the presence of microabscesses in the brainstem, with presence of non-suppurative meningoencephalitis (Rissi et al. 2010c, Konradt et al. 2017). The location of the lesions in brainstem is closely related to the bacteria invading the oral mucosa, and by extension invading the trigeminal nerves, therefore, traveling centripetally via axons to the brain (Cantile \& Youssef 2016). Cases of listeriosis are frequently associated with feeding the animals with poor quality silage (Rissi et al. 2010c), and heavy feeding of silage (Cantile \& Youssef 2016). In our study, few animals had a history of silage feeding. Cases of tetanus were also responsible for $2 \%$ of conclusive cases. Like described in our cases, the disease usually occurs after castration, caudectomy, dehorn, lambing and contamination of vaccine sites (Driemeier et al. 2007). The diagnosis must be performed through the association of history of handling and clinical signs (Rissi et al. 2010c). Common clinical signs are stiffness, rigidity of the neck and limbs, prolapse of the third eyelid, teeth grinding, hypersensitivity, tachycardia, hyperthermia, recumbency with extension of the limbs, and opistotonus (Driemeier et al. 2007).

The category with more cases after infectious non-parasitic, was the toxic. The most common type of poisoning was caused by Baccharis coridifolia. This plant, also known as "mio-mio", is one of the most common toxic plants in South Brazil (Rozza et al. 2006, Hammerschmitt et al. 2018). Poisoning outbreaks frequently occur when animals are transported from areas without the plant to areas with the plant, especially when they are hungry, thirsty and stressed after transportation (Rozza et al. 2006, Hammerschmitt et al. 2018). This type of poisoning is acute and clinical signs are consistent with apatia, anorexia, incoordination, diarrhea, recumbency and death in only 4 hours after the consumption (Rozza et al. 2006). Gross lesions are characterized by edema of the rumen wall, ruminal and abomasal erosions and ulcers, and reddened submucosa (Rozza et al. 2006). Histologically, degenerative and necrotic lesions of the epithelium of forestomachs and abomasum are the main findings (Rozza et al. 2006, Hammerschmitt et al. 2018). In our study, most cases occurred as an outbreak, with similar epidemiology, gross and histological lesions, as described in the literature.

Sheep are highly susceptible to copper poisoning, and in our study this disease corresponded to $4 \%$ of the conclusive cases, similar to other authors (Rissi et al. 2010b, Almeida et al. 2013). In our study, most cases occurred in properties where sheep had access to cattle feed or grape marc, a byproduct of the wine industry. Copper poisoning due to grape marc ingestion results from the high contents of the metal in vineyards sprayed with copper-based fungicides (Reis et al. 2015). The gross and microscopic features, such as jaundice and hepatic necrosis were similar to the literature (Rissi et al. 2010b, Bandinelli et al. 2013, Miguel et al. 2013).
Brachiaria sp. poisoning, leading to hepatogenous photosensitization was responsible for $2 \%$ of conclusive diagnoses. This frequency is lower than what is observed in the Midwest, where the plant is extensively cultivated, and poisoning by Brachiaria sp. was responsible for $13.9 \%$ of total causes of death (Almeida et al. 2013). Sheep are more susceptible to this plant poisoning than other animal species and the young are more susceptible than adults, as also observed in our study (Riet-Correa et al. 2011). Brachiaria species are frequently cultivated in Brazil, mainly in the Midwest, and are considered one of the most important forages; however, the limiting factor is the toxicity responsible for hepatogenous photosensitization, decrease in productivity, and death. This condition is associated with severe economic losses not only directly related to high mortality, but also due to weight loss, and extensive skin lesions (Mustafa et al. 2009). In a review of the frequency of 18 outbreaks of Brachiaria poisoning in sheep in Central Brazil, the mortality rate was $15-42.8 \%$ (Mustafa et al. 2009). Usually, gross and microscopic lesions observed are consistent with dermatitis and hepatic necrosis (Mustafa et al. 2009, Almeida et al. 2013), as also observed in our cases. In other cases of hepatic photosensitization and acute toxic liver disease, no compounds or plants could be identified; however, the gross and microscopic features suggested a toxic cause. Some plants and larvae are recognized to cause acute liver necrosis in cattle and sheep, especially in Rio Grande do Sul, and may be involved in our cases, such as Xanthium cavanillesii, Cestrum spp., Dodonea viscosa, Trema micrantha, Senecio spp., and Perreyia flavipes larvae (Raymundo et al. 2008, Rissi et al. 2010 b). However, photosensitization in sheep has only been associated with chronic consumption of Senecio spp. (Grecco et al. 2011), and Brachiaria spp. (Mustafa et al. 2009), and neither of these plants were identified related to our cases.

Ionophore poisoning is usually caused by salinomycin, monensin, lasalocid, narasin, and maduramicin. Ionophores and carboxylic polyether antibiotics present antimicrobial and anticoccidial properties (França et al. 2009). Ionophores toxicity varies considerably among species, with horses being the most sensitive. Toxicity may occur after accidental access to medicated feed, errors in feed mixing, deliberate feeding of a ration formulated for a less sensitive species, and or concurrent use of some products with known interactions such as tiamulin, oleandomycin, chloramphenicol, erythromycin, and sulfonamides (Roder \& McCoy 1999). Clinical signs of incoordination as a result of flaccid paralysis are frequent, and sheep usually die due to heart failure. The gross findings of pale areas in cardiac and skeletal muscle are histologically compatible with necrosis of muscular fibers (França et al. 2009). The clinical, epidemiological, and histopathological features observed in our cases, presented as outbreaks, in which the poisoning occurred after the consumption of monensin, due to feeding the sheep with cattle feed, are similar to those described in the literature (França et al. 2009, Ashrafihelan et al. 2014).

Even while the infectious non-parasitic and toxic categories presented more cases, the main cause of death in sheep in this study was related to parasitic disease, mainly haemonchosis, and frequently affected sheep with a median age of 18 months which is in accordance with the literature (Rissi et al. 2010b). Similar results were also diagnosed in the Midwest region of Brazil, where $22.2 \%$ of sheep deaths 
were caused by Haemonchus sp. (Almeida et al. 2013). The clinical and pathological findings associated with this condition were severe anemia and hypoproteinemia (Uzal et al. 2016). The diagnosis can be performed based on necropsy findings of pale mucous membranes and carcass, submandibular edema, ascites, and direct observation of the parasites in the abomasum (Rissi et al. 2010b). Histologically, degeneration, or paracentral to centrilobular necrosis of hepatocytes is the main feature (Rissi et al. 2010b, Uzal et al. 2016). Although some sheep may present all the clinical signs of haemonchosis, in some cases it is not possible to observe the parasites in the abomasum, therefore the diagnosis must be performed with the association of clinical signs, and some pathological features such as anemia. This absence of parasites is frequently related to the fact that the sheep had been recently treated with anthelmintic drugs (Rissi et al. 2010b). Infections with Haemonchus contortus, in particular with strains resistant to anthelmintics are common, and the repeated use of individual products or products in the same drug class will invariably lead to resistance (Taylor 2012). In Southern Brazil, studies had demonstrated multiple parasite resistance to all classes of anthelmintic drugs available for small ruminants in the Brazilian market (Cezar et al. 2010), explaining the main reason why haemonchosis remains the main cause of death in sheep when compared to older studies (Rissi et al. 2010b, Correa 2014).

About the nutritional and metabolic etiologies, the most common disease was ruminal acidosis, followed by urolithiasis. Ruminal acidosis is frequently associated with an abrupt change in the animal diet, as also noticed in our cases, leading to the consumption of high fermentation carbohydrates, in the form of grain, which promotes the growth of Gram-positive bacteria and the production of lactic acid (Gelberg 2013). The gross findings of this metabolic disease are nonspecific, and the diagnosis requires the association of animal access to fermentable carbohydrates and a clinical feature of circulatory failure (Uzal et al. 2016). As observed in our cases, rumenitis may be present and characterized histologically by marked cytoplasmic vacuolation of the rumen epithelial cells (Uzal et al. 2016). Urolithiasis can affect both males or females; however, obstruction due to urolithiasis is more common in males, as observed in our cases where all sheep affected were male, and this sex predisposition is related to anatomical characteristics of the urinary tract in males like smaller urethral diameter, sigmoid flexure, and urethral process (Riet-Correa et al. 2008).

In the 'others' category, trauma was the main cause of death. As already mentioned, all cases were caused by accidents involving other species, mainly dogs. In the congenital defects category, the causes of death included arthrogryposis, congenital microphthalmia, hydrocephalus, and spina bifida. Several conditions and causes can lead to malformations in the ovine species, including genetic disorders, viruses (pestivirus, Akabane virus, Schmallenberg virus, and Cache Valley virus), and toxic agents (Mimosa tenuiflora) (Kennedy \& Miller 1993, de la Concha-Bermejillo 2003, Pimentel et al. 2007) however, we were unable to determine the causes of sheep malformations in this study.

\section{CONCLUSIONS}

The main causes of death in sheep in the State of Rio Grande do Sul, from January 2004 to December 2019 were associated with infectious non-parasitic, toxic and infectious parasitic diseases.

The main diagnosis was haemonchosis, followed by pneumonia, and poisoning by Baccharis coridifolia. The epidemiological and pathological data presented in this study can help field veterinarians to identify the main lesions associated with the disease here described.

Acknowledgments.- The authors would like to thank "Conselho Nacional de Desenvolvimento Científico e Tecnológico" (CNPq) and "Coordenação de Aperfeiçoamento de Pessoal de Nível Superior" (CAPES) - Finance Code 001, for financial support. The authors gratefully acknowledge members of the "Setor de Patologia Veterinária" (SPV) from the "Universidade Federal do Rio Grande do Sul" (UFRGS).

Conflict of interest statement.- The authors declare no conflict of interest.

\section{REFERENCES}

Almeida T.L., Brum K.B., Lemos R.A.A., Leal C.R.B. \& Borges F.A. 2013. Doenças de ovinos diagnosticadas no Laboratório de Anatomia Patológica Animal da Universidade Federal de Mato Grosso do Sul (1996-2010). Pesq. Vet. Bras. 33(1):21-29. <https://dx.doi.org/10.1590/S0100-736X2013000100005>

Antoniassi N.A.B., Pavarini S.P., Henzel A., Flores E.F. \& Driemeier D. 2010a. Aspiration pneumonia associated with oesophageal myonecrosis in sheep due to BTV infection in Brazil. Vet. Rec. 166(2):52-53. <https://dx.doi. org/10.1136/vr.b4775> <PMid:20064980>

Antoniassi N.A.B., Pavarini S.P., Ribeiro L.A.O., Silva M.S., Flores E.F. \& Driemeier D. 2010b. Alterações clínicas e patológicas em ovinos infectados naturalmente pelo vírus da língua azul no Rio Grande do Sul. Pesq. Vet. Bras. 30(12):10101016. <https://dx.doi.org/10.1590/S0100-736X2010001200002>

Ashrafihelan J., Eisapour H., Erfani A.M., Kalantary A.A., Amoli J.S. \& Mozafari M. 2014. High mortality due to accidental salinomycin intoxication in sheep. Interdiscip. Toxicol. 7(3):173-176. <https://dx.doi.org/10.2478/ intox-2014-0024> <PMid:26109896>

Bandinelli M.B., Pavarini S.P., Gomes D.C., Bassuino D.M., Wurster F., Wouters F., Cruz C.E.F. \& Driemeier D. 2013. Acute copper poisoning in sheep. Ciência Rural 43(10):1862-1865. <https://dx.doi.org/10.1590/S010384782013001000021>

Bassuino D.M., Konradt G., Bianchi M.V., Snel G.G.M., Sonne L., Pavarini S.P. \& Driemeier D. 2018. Causes of death in goats in Rio Grande do Sul state, Brazil: analysis of 322 cases (2000-2016). Pesq. Vet. Bras. 38(11):20802087. <https://dx.doi.org/10.1590/1678-5150-PVB-5765>

Bianchi R.M., Panziera W., Faccin T.C., Almeida G.L., Cargnelutti J.F., Flores E.F., Kommers G.D. \& Fighera R.A. 2017. Clinical, pathological and epidemiological aspects of outbreaks of bluetongue disease in sheep in the central region of Rio Grande do Sul. Pesq. Vet. Bras. 37(12):1443-1452. <https://dx.doi. org/10.1590/S0100-736X2017001200014>

Cantile C. \& Youssef S. 2016. Nervous system, p.250-406. In: Maxie M.G. (Ed.), Jubb, Kennedy and Palmer's Pathology of Domestic Animals. Vol.1. 6th ed. Academic Press, New York.

Caswell J.L. \& Williams K.J. 2016 Respiratory system, p.465-592. In: Maxie M.G. (Ed.), Jubb, Kennedy and Palmer's Pathology of Domestic Animals. Vol.2. 6th ed. Academic Press, New York.

Cezar A.S., Toscan G., Camillo G., Sangioni L.A., Ribas H.O. \& Vogel F.S.F. 2010 Multiple resistance of gastrointestinal nematodes to nine different drugs in a sheep flock in southern Brazil. Vet. Parasitol. 173(1/2):157-160. <https://dx.doi.org/10.1016/j.vetpar.2010.06.013> <PMid:20619543> 
Correa G.L.F. 2014. Estudo retrospectivo das causas de morte de ovinos diagnosticados no setor de patologia veterinária UFRGS: 2002-2012. Master's Thesis, Universidade Federal do Rio Grande do Sul, Porto Alegre. 48p.

de la Concha-Bermejillo A. 2003. Cache Valley virus is a cause of fetal malformation and pregnancy loss in sheep. Small Ruminant Res. 49(1):1-9. <https://dx.doi.org/10.1016/S0921-4488(03)00050-6>

Driemeier D., Schild A.L., Fernandes J.C., Colodel E.M., Corrêa A.M., Cruz C.E. \& Barros C.S.L. 2007. Outbreaks of tetanus in beef cattle and sheep in Brazil associated to disophenol injection. J. Vet. Med. 54(6):333-335. <https:// dx.doi.org/10.1111/j.1439-0442.2007.00922.x> <PMid:17650154>

França T.N., Nogueira V.A., Yamasaki E.M., Caldas S.A., Tokarnia C.H. \& Peixoto P.V. 2009. Intoxicação acidental por monensina em ovinos no Estado do Rio de Janeiro. Pesq. Vet. Bras. 29(9):743-746. <https://dx.doi.org/10.1590/ S0100-736X2009000900011>

Gelberg H.B. 2013. Sistema alimentar, peritônio, omento, mesentério cavidade peritoneal, p.323-406. In: Zachary J. \& McGavin M.D. (Eds), Bases da Patologia Veterinária. 5a ed. Elsevier. Rio de Janeiro.

Grecco F.B., Estima-Silva P., Marcolongo-Pereira C., Soares M.P., Collares G. \& Schild A.L. 2011. Chronic seneciosis in sheep in southern Rio Grande do Sul, Brazil. Pesq. Vet. Bras. 31(4):326-330. <https://dx.doi.org/10.1590/ S0100-736X2011000400009>

Guimarães L.L.B., Rosa J.C.C., Matos A.C.D., Cruz R.A.S., Guedes M.I.M.C., Dorella F.A., Figueiredo H.C.P., Pavarini S.P., Sonne L., Lobato Z.I.P. \& Driemeier D. 2017. Identification of bluetongue virus serotypes 1 , 4, and 17 co-infections in sheep flocks during outbreaks in Brazil. Res. Vet. Sci. 113:87-93. <https:// dx.doi.org/10.1016/j.rvsc.2017.09.001><PMid:28918235>

Hammerschmitt M.E., Panziera W., Vielmo A., Argenta F., Arruda N.S., Horn J.A., Pavarini S.P. \& Driemeier D. 2018. Spontaneous Baccharis coridifolia poisoning in suckling lambs. Acta Sci. Vet. 46(1):316. <https://dx.doi. org/10.22456/1679-9216.87474>

IBGE 2018. Tabela 3939 - Efetivo dos rebanhos, por tipo de rebanho. Pesquisa da Pecuária Municipal, Instituto Brasileiro de Geografia e Estatística, Rio de Janeiro. Available at <https://sidra.ibge.gov.br/tabela/3939\# resultado> Accessed on Oct. 16, 2020.

Kennedy P.C. \& Miller R.B. 1993. The female genital tract, p.349-470. In: Maxie M.G. (Ed.), Jubb, Kennedy and Palmer's Pathology of Domestic Animals. Academic Press, San Diego.

Konradt G., Bassuino D.M., Prates K.S., Bianchi M.V., Snel G.M., Sonne L., Driemeier D. \& Pavarini S.P. 2017. Suppurat1ive infectious diseases of the central nervous system in domestic ruminants. Pesq. Vet. Bras. 37(8):820828. <https://dx.doi.org/10.1590/S0100-736X2017000800007>

Miguel M.P., Souza M.A., Cunha P.H.J., Costa G.L. \& Abud L.J. 2013. Intoxicação crônica por cobre em ovinos: conduta para o diagnóstico conclusivo. Arq. Bras. Med. Vet. Zootec., 65(2):364-368. <https://dx.doi.org/10.1590/ S0102-09352013000200010>

Mustafa V.S. 2009. Intoxicação por Brachiaria spp em ovinos no Brasil Central. Master's Thesis, Universidade de Brasília, Brasília, DF. 71p.
Pimentel L.A., Riet-Correa F., Gardner D., Panter K.E., Dantas A.F.M., Mederiso R.M.T., Mota R.A. \& Araújo J.A.S. 2007. Mimosa tenuiflora as a cause of malformations in ruminants in the Northeastern Brazilian semiarid rangelands. Vet. Pathol. 44(6):928-931. <https://dx.doi.org/10.1354/ vp.44-6-928><PMid:18039908>

Raymundo D.L., Bezerra Junior P.S., Bandarra P.M., Pedroso P.M.O., Oliveira E.C., Pescador C.A. \& Driemeier D. 2008. Spontaneous poisoning by larvae of Perreyia flavipes (Pergidae) in sheep. Pesq. Vet. Bras. 28(1):19-22. <https://dx.doi.org/10.1590/S0100-736X2008000100003>

Reis M.O., Mello L.S., Cruz R.A.S., Guimarães L.L., Oliveira L.G.S., Lorenzett M.P., Pavarini S.P. \& Driemeier D. 2015. Chronic copper toxicity in sheep fed grape marc. Acta Scient. Vet. 43(Supl.1):108.

Riet-Correa B., Castro M.B., Lemos R.A.A., Riet-Correa G., Mustafa V. \& Riet-Correa F. 2011. Brachiaria spp. poisoning of ruminants in Brazil. Pesq. Vet. Bras. 31(3):183-192. <https://dx.doi.org/10.1590/S0100736X2011000300001>

Riet-Correa F., Simões S.V.D. \& Vasconcelos J.S. 2008. Urolitíase em caprinos e ovinos. Pesq. Vet. Bras. 28(6):319-322. <https://dx.doi.org/10.1590/ S0100-736X2008000600010>

Rissi D.R., Fighera R.A., Irigoyen L.F., Kommers G.D. \& Barros C.S.L. 2010a. Doenças neurológicas de ovinos na região central do Rio Grande do Sul. Pesq. Vet. Bras. 30(3):222-228. <https://dx.doi.org/10.1590/S0100736X2010000300006>

Rissi D.R., Kommers G.D., Marcolongo-Pereira C., Schild A.L. \& Barros C.S.L. 2010c. Meningoencefalite por Listeria monocytogenes em ovinos. Pesq. Vet. Bras. 30(1):51-56. <https://dx.doi.org/10.1590/S0100-736X2010000100008>

Rissi D.R., Pierezan F., Oliveira Filho J.C., Fighera R.A., Irigoyen L.F., Kommers G.D. \& Barros C.S.L. 2010b. Doenças de ovinos da região Central do Rio Grande do Sul: 361 casos. Pesq. Vet. Bras. 30(1):21-28. <https://dx.doi. org/10.1590/S0100-736X2010000100004>

Roder J.D. \& McCoy C.P. 1999. Ionophore toxicoses, p.244-249. In: Howard J.L. (Ed.), Current Veterinary Therapy: food animal practice. W.B. Saunders, Philadelphia.

Rozza D.B., Raymundo D.L., Corrêa A.M.R., Leal J., Seitz A.L., Driemeier D. \& Colodel E.M. 2006. Intoxicação espontânea por Baccharis coridifolia (Compositae) em ovinos. Pesq. Vet. Bras. 26(1):21-25. <https://dx.doi. org/10.1590/S0100-736X2006000100005>

Taylor M.A. 2012. Emerging parasitic disease. Vet. Parasitol. 189(1):2-7. <https://dx.doi.org/10.1016/j.vetpar.2012.03.027><PMid:22525586>

Uzal F.A., Plattner B.L. \& Hostetter J.M. 2016. Alimentary system, p.1-259. In: Maxie M.G. (Ed.), Jubb, Kennedy and Palmer's Pathology of Domestic Animals. Academic Press, San Diego.

Viana J.G.A. \& Silveira V.C.P. 2009. Análise econômica da ovinocultura: estudo de caso na metade Sul do Rio Grande do Sul, Brasil. Ciência Rural 39(4):11761181. <https://dx.doi.org/10.1590/S0103-84782009005000030> 